\title{
PENGARUH SALINITAS TERHADAP KELANGSUNGAN HIDUP dan PERTUMBUHAN LELE DUMBO (Clarias gariepinus)
}

\author{
Oleh: \\ Azam B. Zaidy \\ Dosen Jurusan Penyuluhan Perikanan Sekolah Tinggi Perikanan
}

\begin{abstract}
ABSTRAK
Lele merupakan komoditas ikan air tawar komersial dapat dibudidayakan di lahan dan sumber air yang terbatas dengan padat tebar tinggi, teknologi budidaya relatif mudah dikuasai oleh masyarakat, pemasarannya relatif mudah dan modal usaha yang dibutuhkan relatif rendah. Tujuan penelitian ini adalah mengetahui tingkat kelangsungan hidup dan pertumbuhan lele yang dipelihara pada salinitas yang berbeda.

Uji adaptasi lele ini dilaksanakan pada bulan Oktober - Desember 2008, bertempat di hatchery Program Studi Penyuluhan Perikanan Sekolah Tinggi Perikanan. Desain percobaan menggunakan rancangan acak lengkap (RAL) dengan 3 perlakuan yaitu perbedaan salinitas media sebesar 0,5 dan 10 ppt dengan masing-masing 3 ulangan. Benih lele dengan berat rata-rata $6.5 \mathrm{~g}$ sebanyak 10 ekor, dimasukkan ke dalam akuarium 90 x 40 x $40 \mathrm{~cm}$. Selama percobaan ikan diberi pakan pellet sebanyak 3-5\%/hari dengan frekuensinya 3 kali/hari. Parameter yang diukur suhu, salinitas, $\mathrm{pH}, \mathrm{DO}$, bahan organik, pertumbuhan individu, kelangsungan hidup dan biomas. Hasil analisis data akan dibandingkan kelangsungan hidup dan pertumbuhan lele antar perlakuan.

Kondisi kualitas air dengan salinitas 0,5 dan 10 ppt selama percobaan cukup layak untuk kehidupan lele dan dapat tumbuh dengan baik. Kelangsungan hidup lele yang dipelihara pada lingkungan dengan salinitas 0, 5 dan 10 ppt yaitu sama $100 \%$. Perkembangan biomas pada pada salinitas 0,5 dan 10 ppt sampai hari ke 20 tidak berbeda nyata. Pada hari ke 30 sampai dengan hari ke 50, lele yang dipelihara di salinitas 0 dan 5 ppt memiliki berat biomas lebih tinggi dibandingkan lele yang hidup di salinitas $10 \mathrm{ppt}$.
\end{abstract}

Kata Kunci : Lele dumbo, pertumbuhan, salinitas, DO, pH, Biomas, bahan organik

\section{PENDAHULUAN}

\section{Latar Belakang}

Lele dumbo (Clarias gariepinus). yang berasal dari Benua Afrika masuk ke Indonesia tahun 1984 berkembang dengan cepat, karena memiliki kelebihan diantaranya pertumbuhannya cepat, daya adaptasi terhadap lingkungan cukup baik, dan mudah diterima masyarakat.

Lele merupakan komoditas ikan air tawar komersial : 1) dapat dibudidayakan di lahan dan sumber air yang terbatas dengan padat tebar tinggi, 2) teknologi budidaya relatif mudah dikuasai oleh masyarakat, 3) pemasarannya relatif mudah dan 4) modal usaha yang dibutuhkan relatif rendah.

Beberapa jenis ikan air tawar seperti ikan Nila, ikan Mas dan Udang Galah dapat hidup dan tumbuh dengan baik di perairan dengan salinitas di bawah 15 ppt, bahkan memiliki rasa daging yang lebih enak. Pada benih lele (Clarias lazera) ukuran 52-88 mm dengan 
kelangsungan hidup 94\% dipindahkan dari salinitas $0.4 \mathrm{ppt}$ ke salintas $9.5 \mathrm{ppt}$ secara bertahap.(Chervinski, 1983), sedangkan pada benih lele Afrika dapat hidup dengan baik pada salinitas maksium $10 \mathrm{ppt}$, daya tetas telur tinggi pada salinitas maksimum 5 ppt dan tidak menetas pada salinitas 8 ppt (Gbulubo dkk, 1995).

Sejauh ini keberhasilan usaha pembesaran lele di daerah pesisir belum berkembang pesat. Hal ini dikarenakan masih kurangnya informasi tentang salinitas yang optimal bagi pertumbuhan lele. Berdasarkan uraian tersebut di atas perlu dilakukan penelitian yang terkait kemampuan hidup ikan lele di perairan payau.

\section{Tujuan}

Mengetahui tingkat kelangsungan hidup dan pertumbuhan lele yang dipelihara pada salinitas yang berbeda.

\section{METODOLOGI}

\section{Waktu dan Tempat}

Uji adaptasi lele ini dilaksanakan pada bulan Oktober - Desember 2008, bertempat di hatchery Program Studi Penyuluhan Perikanan Sekolah Tinggi Perikanan.

\section{Desain dan Prosedur Percobaan}

Desain percobaan menggunakan rancangan acak lengkap (RAL) dengan 3 perlakuan yaitu perbedaan salinitas media sebesar 0, 5 dan $10 \mathrm{ppt}$ dengan masingmasing 3 ulangan. Benih lele dengan berat rata-rata $6.5 \mathrm{~g}$ sebanyak 10 ekor, dimasukkan ke dalam akuarium 90 x 40 x $40 \mathrm{~cm}$. Selama percobaan ikan diberi pakan pellet sebanyak 3-5\%/hari dengan frekuensinya $3 \mathrm{kali} / \mathrm{hari}$. Parameter yang diukur suhu, salinitas, $\mathrm{pH}$, DO, bahan organik, pertumbuhan individu, kelangsungan hidup dan biomas

\section{Analisis Data}

- Membandingkan kelangsungan hidup antar perlakuan

- Membandingkan laju pertumbuhan antar perlakuan

- Membandingkan biomas akhir antar perlakuan

- Membandingkan FCR antar perlakuan

\section{HASIL DAN PEMBAHASAN}

\section{Kualitas Air}

Hasil pengamatan kualitas air selama percobaan dapat dilihat pada Tabel 1

Tabel 1. Kondisi Kualitas Air Selama Percobaan

\begin{tabular}{ccccccc}
\hline $\begin{array}{c}\text { Ha } \\
\text { ri }\end{array}$ & Perlakuan & Salinitas (ppt) & pH & $\begin{array}{c}\text { DO } \\
(\mathbf{p p m})\end{array}$ & $\begin{array}{c}\text { Alkalinitas } \\
(\mathbf{C a C O} \mathbf{e q})\end{array}$ & $\begin{array}{c}\text { Bahan } \\
\text { organik } \\
(\mathbf{p p m})\end{array}$ \\
\hline \multirow{2}{*}{1} & 1 & 0 & 5.5 & 2.15 & 26 & 36 \\
& 2 & 5 & 6 & 4.63 & 42 & 36.4 \\
& 3 & 10 & 7 & 5.98 & 59.8 & 35.8 \\
\hline \multirow{2}{*}{10} & 1 & 0 & 5.5 & 4.43 & 27.5 & 89.9 \\
& 2 & 5 & 6.5 & 4.22 & 41 & 92.8
\end{tabular}




\begin{tabular}{ccccccc} 
& 3 & 10 & 7 & 5.43 & 60.7 & 92.8 \\
\hline \multirow{3}{*}{20} & 1 & 0 & 6 & 2.77 & 73.3 & 48 \\
& 2 & 5 & 6 & 2.69 & 81.3 & 72 \\
& 3 & 10 & 6 & 3 & 88 & 84 \\
\hline \multirow{3}{*}{30} & 1 & 0 & 6 & 3.17 & 66.8 & 68 \\
& 2 & 5 & 6.5 & 3.26 & 74.8 & 77 \\
& 3 & 10 & 6.8 & 3.47 & 79 & 82 \\
\hline \multirow{3}{*}{50} & 1 & 0 & 6.2 & 2.89 & 68.2 & 85.3 \\
& 2 & 5 & 6.7 & 3.14 & 72.4 & 86.7 \\
& 1 & 10 & 6.6 & 3.34 & 73.2 & 87.5 \\
\hline & 2 & 0 & 6.5 & 3.23 & 72 & 84 \\
& 3 & 5 & 6.7 & 3.17 & 74.5 & 87.5 \\
\hline
\end{tabular}

Dari tabel tersebut menunjukkan bahwa kondisi kualitas air dengan salinitas 0,5 dan 10 ppt selama percobaan cukup layak untuk kehidupan lele dan dapat tumbuh dengan baik.

Data kualitas memperlihatkan kecenderungan pada peubah $\mathrm{pH}$ dan alkalinitas yaitu semakin tinggi salinitas air maka $\mathrm{pH}$ dan alkalinitas juga semakin tinggi. Hal ini dapat dijelaskan bahwa pada air laut dengan salinitas $30-32 \mathrm{ppt}$ umumnya memiliki nilai $\mathrm{pH}$ sekitar 8, sedangkan pada air tawar dengan salinitas mendekati 0 ppt nilai pH berkisar 6-6.5. Pada air laut memiliki kapasitas buffer yang cukup baik, sehingga dapat menahan penurunan $\mathrm{pH}$ yang terlalu besar. Alkalinitas lebih tinggi pada air dengan salinitas 5 dan 10 dibandingkan kontrol disebabkan karena air laut banyak mengandung garam-garam karbonat. Sedangkan peubah kualitas air yang lain yaitu oksigen terlarut, dan bahan organik terlarut tidak dipengaruhi oleh tingkat salinitas air.

\section{Kelangsungan Hidup}

Hasil pengamatan jumlah ikan yang hidup setiap 10 hari selama percobaan tercantum pada Tabel 2 .

Tabel 2. Jumlah Lele yang Hidup Selama Percobaan

\begin{tabular}{cccc}
\hline \multirow{2}{*}{$\begin{array}{c}\text { Hari } \\
\text { ke- }\end{array}$} & \multicolumn{3}{c}{ Jumlah ikan yang hidup (ekor) } \\
\cline { 2 - 4 } & $\mathbf{0 ~ p p t}$ & $\mathbf{5} \mathbf{~ p p t}$ & $\mathbf{1 0} \mathbf{~ p p t}$ \\
\hline $\mathbf{1}$ & 10 & 10 & 10 \\
$\mathbf{1 0}$ & 10 & 10 & 10 \\
$\mathbf{2 0}$ & 10 & 10 & 10 \\
$\mathbf{3 0}$ & 10 & 10 & 10 \\
$\mathbf{4 0}$ & 10 & 10 & 10 \\
$\mathbf{5 0}$ & 10 & 10 & 10 \\
\hline
\end{tabular}


Kelangsungan hidup lele yang dipelihara pada lingkungan dengan salinitas 0, 5 dan 10 ppt yaitu sama $100 \%$. Hal tersebut menunjukkan bahwa pada salinitas maksimum $10 \mathrm{ppt}$, sistem osmoregulasi pada lele dapat bekerja dengan baik, sehingga dapat hidup dengan baik. Hal tersebut sesuai dengan hasil penelitian Affandi dan Usman (2002), ikan bertulang sejati (telestei), ikan air tawar maupun ikan laut pada dasarnya mempunyai kemampuan untuk mempertahankan komposisi ion-ion dan osmolaritas cairan tubuhnya pada tingkat yang secara signifikan berbeda dari lingkungan eksternalnya. Proses ini merupakan suatu mekanisme dasar osmotik.

\section{Pertumbuhan Biomas}

Hasil pengukuran pekembangan biomas lele setiap 10 hari selama percobaan tercantum pada Gambar 1 .

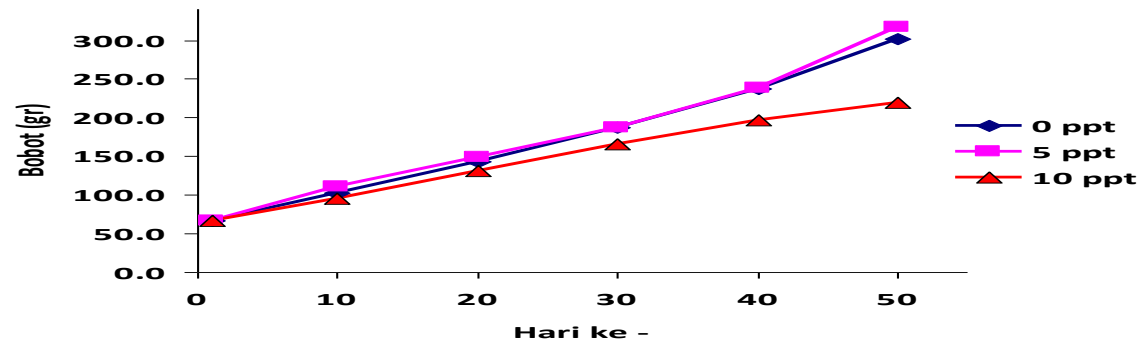

Gambar 1.Grafik Pertumbuhan Berat Selama Percobaan

Hasil analisis ragam menunjukkan bahwa perkembangan biomas pada lingkungan dengan salinitas 0,5 dan 10 ppt sampai hari ke 20 tidak berbeda nyata. Pada hari ke 30 sampai dengan hari ke 50, lele yang dipelihara di salinitas 0 dan 5 ppt memiliki berat biomas lebih tinggi dibandingkan lele yang hidup di salinitas 10 ppt (Gambar 2).
Pengujian lanjut menggunakan LSD (Least Significant Different) pada hari ke 30 sampai dengan hari ke 50, memperlihatkan bahwa berat biomas lele pada perlakuan salinitas 5 ppt lebih tinggi dibandingkan dengan perlakuan lain namun tidak berbeda nyata dengan perlakuan 0 ppt.

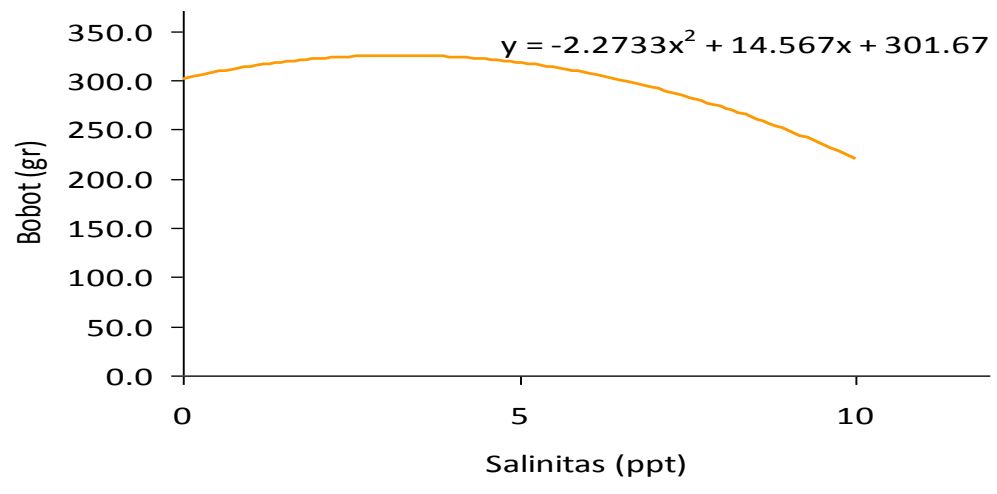

Gambar 2.Pengaruh Salinitas terhadap Biomas Akhir Ikan Lele 


\section{Laju Pertumbuhan}

Laju pertumbuhan ikan lele selama percobaan dapat dilihat pada Gambar 3.

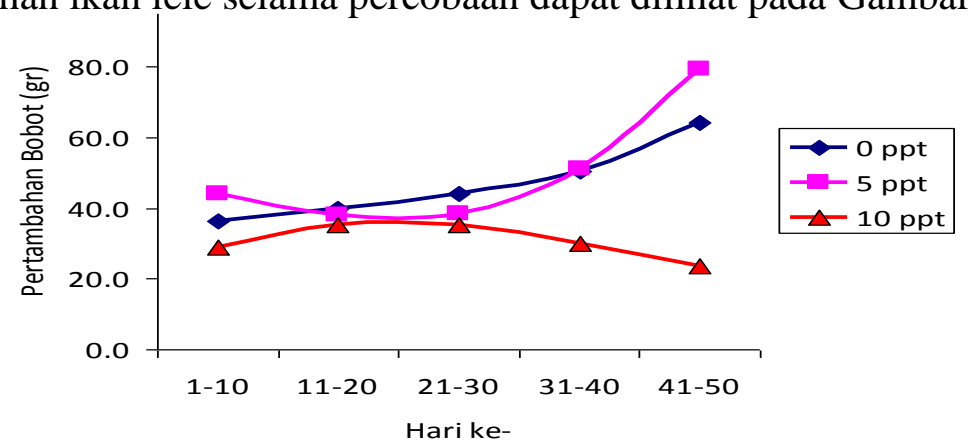

Gambar 3.Laju Pertumbuhan Ikan Lele Selama Percobaan

Dari data sebelumnya bahwa tingkat kelangsungan lele yang dipelihara di salinitas 0, 5 dan 10 ppt selama percobaan tidak berbeda nyata, yaitu tidak terjadi kematian selama percobaan, namun demikian pada hari ke 30 , biomas lele yang diperlihara di salininitas 0 dan 5 ppt perkembangannya lebih cepat dibanding yang dipelihara di salinitas 10 ppt. Hal tersebut dapat dijelaskan bahwa pada lele yang dipelihara pada salinitas $10 \mathrm{ppt}$ diperlukan energi osmoregulasi yang lebih tinggi, sehingga persediaan energi untuk pertumbuhan berkurang. Hal ini sesuai hasil penelitian

Stickney, 1979 dalam Bestian, 1996 bahwa osmoregulasi merupakan suatu fungsi fisiologis yang membutuhkan energi, yang dikontrol oleh penyerapan selektif ion-ion yang melewati insang dan pada beberapa bagian tubuh lainnya dikontrol oleh pembuangan yang selektif terhadap garam-garam.

\section{KESIMPULAN DAN SARAN}

\section{Kesimpulan}

1. Kelangsungan hidup lele yang dipelihara di salinitas 0,5 dan $10 \mathrm{ppt}$ sama yaitu $100 \%$
2. Berat biomas pada hari ke 50 lebih tinggi pada lele yang dipelihara pada salilitas 0 dan 5 ppt dibandingkan yang dipelihara pada salinitas $10 \mathrm{ppt}$

\section{Saran}

Pembesaran lele dapat dilakukan di daerah pesisir dengan salinitas lingkungan kurang dari 10 ppt.

\section{AFTAR PUSTAKA}

Chervinski, J. 1983. Salinity tolerance of young catfish Clarias lazera (Burchell). Department of Fiesheries, P.O.B 699, Haifa 31000 Israel.

Gbulubo, A.J. and E.S. Erondu. 1995. Salinity influence on the early stages of the african catfish. Regional Aquaculture Centre .PM.B, Port Harcourt, Nigeria. 
